\title{
OPEN Water removal during automated peritoneal dialysis assessed by remote patient monitoring and modelling of peritoneal tissue hydration
}

\author{
Joanna Stachowska-Pietka ${ }^{1 凶}$, Beata Naumnik² ${ }^{2}$ Ewa Suchowierska², Rafael Gomez ${ }^{3}$, \\ Jacek Waniewski ${ }^{1}$ \& Bengt Lindholm ${ }^{4}$
}

Water removal which is a key treatment goal of automated peritoneal dialysis (APD) can be assessed cycle-by-cycle using remote patient monitoring (RPM). We analysed ultrafiltration patterns during night $A P D$ following a dry day ( $A P D_{D D}$ i no daytime fluid exchange) or wet day ( $A P D_{W D}$; daytime exchange). Ultrafiltration for each APD exchange were recorded for 16 days using RPM in 14 patients. The distributed model of fluid and solute transport was applied to simulate APD and to explore the impact of changes in peritoneal tissue hydration on ultrafiltration. We found lower ultrafiltration $(\mathrm{mL}$, median [first quartile, third quartile]) during first and second vs. consecutive exchanges in $A P D_{D D}(-61$ $[-148,27], 170[78,228]$ vs. $213[126,275] \mathrm{mL} ; \mathrm{p}<0.001)$, but not in $\operatorname{APD}_{\mathrm{WD}}(81[-8,176], 81[-4,192]$ vs. $115[4,219] \mathrm{mL}$; NS). Simulations in a virtual patient showed that lower ultrafiltration (by $114 \mathrm{~mL}$ ) was related to increased peritoneal tissue hydration caused by inflow of $187 \mathrm{~mL}$ of water during the first $A P D_{D D}$ exchange. The observed phenomenon of lower ultrafiltration during initial exchanges of dialysis fluid in patients undergoing $A P D_{D D}$ appears to be due to water inflow into the peritoneal tissue, re-establishing a state of increased hydration typical for peritoneal dialysis.

In peritoneal dialysis (PD), efficient removal of excess water by peritoneal ultrafiltration is a key treatment goal and a predictor of patient survival ${ }^{1}$. Peritoneal ultrafiltration depends on interactions between dialysis fluid and the peritoneal tissue in which embedded blood capillaries and lymphatics form a complex peritoneal transport system, usually denoted peritoneal membrane, serving as a natural dialysis filter. Various mathematical methods have been used to explore the complex relations between net ultrafiltration and peritoneal tissue properties ${ }^{2-5}$.

Net ultrafiltration - which is a function of transcapillary ultrafiltration, driven by the osmotic force induced by hypertonic dialysis fluid, and water reabsorption from the peritoneal cavity-is influenced by factors such as infused volume, the effective peritoneal surface area in contact with dialysis fluid and exposure time of dialysis fluid in full contact with the peritoneal membrane. These factors vary considerably in automated peritoneal dialysis (APD). APD is typically performed during the night, preceded either by a "dry day" $\left(\mathrm{APD}_{\mathrm{DD}}\right)$ without intraperitoneal dialysate for the whole daytime (except for the residual volume remaining after drainage), or by a "wet day" $\left(\mathrm{APD}_{\mathrm{WD}}\right)$ with dialysate left in the peritoneal cavity for a single or sometimes two long daytime dwells. Water removal during each APD exchange might be expected not to differ if prescriptions of volume infused, dwell time, and glucose concentrations remain constant, but it is not known if the 12- to 14-h rest of peritoneum in $\mathrm{APD}_{\mathrm{DD}}$ could influence peritoneal tissue properties and thereby ultrafiltration during the following APD session.

Peritoneal tissue properties may change during PD because hydrostatic and osmotic pressures of the fluid infused into the peritoneal cavity are considerably higher than corresponding pressures in the peritoneal tissue's interstitial fluid, leading to increased hydration of the tissue close to the peritoneal surface, as shown

\footnotetext{
${ }^{1}$ Nalecz Institute of Biocybernetics and Biomedical Engineering, Polish Academy of Sciences, 4 Trojdena Str, 02-109 Warsaw, Poland. ${ }^{2}$ The First Department of Nephrology and Transplantation with Dialysis Unit, Medical University of Bialystok, Bialystok, Poland. ${ }^{3}$ RTS, Cali, Colombia. ${ }^{4}$ Division of Renal Medicine and Baxter Novum, Department of Clinical Science, Intervention and Technology, Karolinska Institutet, Stockholm, Sweden. ${ }^{\square}$ email: jstachowska@ibib.waw.pl
} 


\begin{tabular}{|l|l|l|}
\hline Clinical characteristics & $\begin{array}{l}\mathbf{A P D}_{\text {WD }} \\
\mathbf{n = 8}\end{array}$ & $\begin{array}{l}\mathbf{A P D}_{\mathrm{DD}} \\
\mathbf{n}=\mathbf{6}\end{array}$ \\
\hline Sex, women/men & $4 / 4$ & $3 / 3$ \\
\hline Age, years & $37(24-77)$ & $31.5(24-66)$ \\
\hline Body weight, kg & $65.1(51-110)$ & $67(38-112.9)$ \\
\hline Diastolic blood pressure, $\mathrm{mmHg}$ & $86(67-90)$ & $78(70-110)$ \\
\hline Systolic blood pressure, $\mathrm{mmHg}$ & $138(117-166)$ & $138(124-155)$ \\
\hline PET D/P creat & $0.74(0.66-0.77)$ & $0.80(0.72-0.92)$ \\
\hline Dialysis vintage, months & $12(4-60)$ & $13(10-55)$ \\
\hline Diuresis, $\mathrm{mL}$ & $600(0-2100)$ & $1150(0-2000)$ \\
\hline
\end{tabular}

Table 1. Clinical characteristics of 14 patients undergoing APD with remote patient monitoring allowing recording of volumes of infusion and drainage of dialysate; patients were undergoing APD with wet day regime $\left(\mathrm{APD}_{\mathrm{WD}}\right)$ or dry day regime $\left(\mathrm{APD}_{\mathrm{DD}}\right)$. Data are median $(\min -\mathrm{max})$ if not stated otherwise. For blood pressure and body weight, the mean values for each patient over 16 days were noted. PET $D / P_{\text {creat }}$ - Peritoneal Equilibration Test dialysate-to-plasma concentration of creatinine.

experimentally ${ }^{6}$ and by mathematical modelling of clinical data ${ }^{2,7}$. During $\mathrm{APD}_{\mathrm{WD}}$, with fluid remaining in the peritoneal cavity during daytime, peritoneal tissue hydration could be assumed to remain increased whereas during the long daytime dwell in $\mathrm{APD}_{\mathrm{DD}}$, the hydrostatic pressure and hydration of the peritoneal tissue may conceivably decrease towards physiological levels.

Net ultrafiltration and other aspects of APD treatment can be studied in detail using a new generation of cyclers equipped with device for remote patient monitoring (RPM), which collects dialysis treatment data that can be used to improve patient care by checking adherence to and modifying dialysis prescriptions ${ }^{8-10}$. The advent of APD with RPM allows for systematic monitoring of the kinetics of infused and drained dialysate volume, and therefore also of the net ultrafiltration (UF) for each exchange (cycle) of the APD session.

The aim of this study was to explore possible effects of the preceding day's exchange on net ultrafiltration of the first exchanges of the subsequent APD session. We first investigated if water removal differed between initial and subsequent consecutive APD exchanges in patients on wet and dry day regimes using data collected by RPM. We then attempted to provide a physiological explanation of observed differences of peritoneal fluid transport during APD cycles and the daytime exchange using numerical simulations from mathematical modelling.

\section{Materials and methods}

Patients. In this observational retrospective study, data on ultrafiltration were collected and analysed in patients undergoing APD at the First Department of Nephrology and Transplantation, Medical University of Bialystok, Bialystok, Poland. After excluding patients with variable tonicity of dialysis fluid infused during consecutive night exchanges to avoid the impact of dialysate tonicity on ultrafiltration during initial APD cycles, we included data from 14 patients median age 31.5 (range, 24 to 77) years; seven women; preceding median time on dialysis was 13 (range, 4 to 60 ) months in the present study. Three patients were high transporters $(\mathrm{H})$, nine high-average transporters (HA), and two low-average transporters (LA) according to peritoneal equilibration test (PET). In all patients, net ultrafiltration was investigated using RPM data for each exchange during 16 consecutive days. Six patients received $\mathrm{APD}$ with a dry day regime $\left(\mathrm{APD}_{\mathrm{DD}}\right)$ and 8 patients had a wet day regime $\left(\mathrm{APD}_{\mathrm{WD}}\right)$, see Table 1 . Clinical characteristics were similar $(\mathrm{p} \geq 0.5$; Mann-Whitney $\mathrm{U}$ test $)$ albeit with tendency for faster small solute transport rate in $\mathrm{APD}_{\mathrm{DD}}$ vs. $\mathrm{APD}_{\mathrm{WD}}\left(\mathrm{p}>0.1\right.$ for $\left.\mathrm{PET} \mathrm{D} / \mathrm{P}_{\text {creat }}\right)$. No clinical evidences of presence of systemic edema or changes of the fluid status were reported during the investigated time period.

The study was conducted according to the principles of Declaration of Helsinki. Ethical approval for this study was obtained from Bioethical Commission of the Medical University of Bialystok (APK.002.225.2020). Informed consent to use retrospective routine clinical data and to publish anonymized data was obtained from the patients.

All patients used APD with RPM (HomeChoice Claria with the Sharesource connectivity platform; Baxter Healthcare Corporation, Deerfield, Il, USA). For night APD exchanges, the patients used glucose-based dialysis fluid (Dianeal or Physioneal with glucose $1.36 \%$ or $2.27 \%$, Baxter, Castlebar, Ireland), and for daytime exchanges, icodextrin-based (Extraneal, Baxter, Castlebar, Ireland) or glucose-based (Physioneal or Dianeal glucose 1.36\% or $2.27 \%$ ) solution; see Table 2 . The number of night cycles varied between patients from 4 to 7 with median 5 cycles in both groups. There were no statistically significant differences between $\mathrm{APD}_{\mathrm{WD}}$ and $\mathrm{APD}_{\mathrm{DD}}$ group with respect to infused volume, number of cycles per APD session, or total glucose load for night APD session; however, as expected, infused volume for daytime exchanges and the glucose/carbohydrate load were higher $(\mathrm{p}=0.002)$ in $\mathrm{APD}_{\mathrm{WD}}$ group. For each patient, the net ultrafiltered volume, measured as a difference between infused and drained volume, were noted for each exchange by the cycler, each day for 16 consecutive days.

As a routine procedure, to avoid pain associated with low fluid volume in the peritoneal cavity after day dwell in patients on the $\mathrm{APD}_{\mathrm{DD}}$ regime, a small volume of dialysis fluid (minimum of $100 \mathrm{~mL}$, up to $500 \mathrm{~mL}$ in some $\mathrm{APD}_{\mathrm{DD}}$ patients) was infused after the last night APD cycle.

Calculations. Data on infused and drained volume from each APD cycle and day exchange were analysed for each patient over a period of 16 days. The values of the net ultrafiltration obtained after first (C1) and second (C2) cycle were compared with the mean ultrafiltration volume from remaining consecutive cycles (cycle 3 and 


\begin{tabular}{|c|c|c|}
\hline Dialysis exchanges & $\begin{array}{l}\mathrm{APD}_{\mathrm{WD}} \\
\mathrm{n}=\mathbf{8}\end{array}$ & $\begin{array}{l}\mathrm{APD}_{\mathrm{DD}} \\
\mathbf{n}=\mathbf{6}\end{array}$ \\
\hline \multicolumn{3}{|l|}{ Night APD exchanges } \\
\hline \multicolumn{3}{|l|}{ Fluid type } \\
\hline Glucose $1.36 \%$ & $50 \%$ & $50 \%$ \\
\hline Physioneal 1.36\% & $25 \%$ & $33 \%$ \\
\hline Dianeal $1.36 \%$ & $25 \%$ & $17 \%$ \\
\hline Glucose $2.27 \%$ & $50 \%$ & $50 \%$ \\
\hline Physioneal 2.27\% & $44 \%$ & $50 \%$ \\
\hline Dianeal $2.27 \%$ & $6 \%$ & $0 \%$ \\
\hline Total number of cycles & $5(4-6)$ & $5(4-7)$ \\
\hline Volume infused per cycle, $\mathrm{mL}$ & $1850(1600-2000)$ & $1800(1600-2300)$ \\
\hline Glucose load, g/session & $152(109-259)$ & $165(116-254)$ \\
\hline \multicolumn{3}{|l|}{ Day exchange } \\
\hline \multicolumn{3}{|l|}{ Fluid type } \\
\hline Glucose $1.36 \%$ & $13 \%$ & $50 \%$ \\
\hline Physioneal 1.36\% & $13 \%$ & $33 \%$ \\
\hline Dianeal 1.36\% & $0 \%$ & $17 \%$ \\
\hline Glucose $2.27 \%$ & $0 \%$ & $50 \%$ \\
\hline Physioneal $2.27 \%$ & $0 \%$ & $50 \%$ \\
\hline Dianeal $2.27 \%$ & $0 \%$ & $0 \%$ \\
\hline Icodextrin (extraneal) 7.5\% & $87 \%$ & $0 \%$ \\
\hline Volume infused, $\mathrm{mL}$ & $1450(1000-1800)$ & $100(100-500)^{* *}$ \\
\hline Carbohydrate/glucose load, g/exchange & $109(14-135)$ & $2(1-7)^{\star *}$ \\
\hline
\end{tabular}

Table 2. Characteristics of automated peritoneal dialysis (APD) schemes prescribed for 8 patients on wet day $\left(\mathrm{APD}_{\mathrm{WD}}\right)$ and for 6 patients with dry day $\left(\mathrm{APD}_{\mathrm{DD}}\right)$ regimes and comparison of $\mathrm{APD}_{\mathrm{WD}}$ with $\mathrm{APD}_{\mathrm{DD}}$ group. Data are presented as percentage, or median $(\min -\max ) .{ }^{* *} \mathrm{p}=0.002$; difference $\mathrm{APD}_{\mathrm{WD}} \mathrm{Vs}$. $A P D_{\mathrm{DD}}$ (Mann-Whitney $U$ test). In $\mathrm{APD}_{\mathrm{DD}}$ group, 4 patients received $100 \mathrm{~mL}, 1$ patient $300 \mathrm{~mL}$ and 1 patient $500 \mathrm{~mL}$ of glucose $1.36 \%$ dialysis fluid for day exchange (to avoid pain during the daytime and subsequent first APD exchange).

subsequent cycles, maximally up to 7), denoted by $\mathrm{C}^{+}$. For each patient, net UF was calculated for night and day sessions separately and for the whole 24 -h period. Daily water removal was calculated as the sum of net UF from night and day exchanges, plus daily diuresis. In one patient, one measurement of ultrafiltration from a day exchange was excluded due to an abnormal value.

Because dialysis fluid tonicity differed between patients from the two study groups, and drained volume depends on the glucose concentration in dialysate, we performed additional analyses of drain volume from first $\left(\mathrm{VdrR}_{1}\right)$ or second $\left(\mathrm{VdrR}_{2}\right)$ exchange over mean drain volume from all remaining exchanges, $\mathrm{UF}_{\mathrm{C} 3+}$, calculated as: $\mathrm{VdrR}_{\mathrm{Ci}}=\mathrm{UF}_{\mathrm{Ci}} / \mathrm{UF}_{\mathrm{C} 3+}$, where $i$ stands for first or second cycle.

Peritoneal transport model. The spatially distributed model that considers tissue hydration status ${ }^{7}$ was applied to simulate peritoneal transport during $\mathrm{APD}_{\mathrm{DD}}$; see Supplementary data for details. In brief, computer simulations were performed for a typical patient undergoing standard APD with six 90 min cycles with infused volume of $2 \mathrm{~L}$ of glucose $1.36 \%$ followed by dry day regime with infused volume of $100 \mathrm{~mL}$ of glucose $1.36 \%$.

Statistical methods. The differences among ultrafiltration volumes after first, second and remaining cycles were analysed using repeated measures analysis of variance (ANOVA) with multivariate tests. If ANOVA showed a significant difference, the post-hoc Tukey's test was applied. The differences between the two variables were checked using Student t-test, Mann-Whitney U test, or Wilcoxson tests, as appropriate. The statistical significance level was set at $\mathrm{p}=0.05$, and data were presented as median [first quartile Q1, third quartile Q3], if not stated otherwise.

\section{Results}

The characteristics of water removal were calculated for each patient undergoing $\mathrm{APD}_{\mathrm{DD}}$ and $A \mathrm{PD}_{\mathrm{WD}}$ for each exchange, for 16 days. Due to high day-to-day variability of UF volumes for essentially all patients, we report median UF volumes calculated for each patient for the whole period of 16 days (Table 3 ). No significant differences were found between $\mathrm{APD}_{\mathrm{DD}}$ and $\mathrm{APD}_{\mathrm{WD}}$ concerning the night and day UF, total peritoneal net UF, diuresis and total $24 \mathrm{~h}$ water removal ( $\mathrm{p}>0.1$; Mann-Whitney $\mathrm{U}$ test).

In patients on $A P D_{D D}$, but not in those receiving $A P D_{W D}$, the initial cycle was consistently associated with lower net UF compared with subsequent cycles (Fig. 1, upper panel). To better illustrate this phenomenon, the 


\begin{tabular}{|l|l|l|}
\hline Water removal, $\mathbf{m L}$ & $\begin{array}{l}\mathbf{A P D}_{\mathbf{W D}} \\
\mathbf{n}=\mathbf{8}\end{array}$ & $\begin{array}{l}\mathbf{A P D}_{\text {DD }} \\
\mathbf{n}=\mathbf{6}\end{array}$ \\
\hline Night net UF & $425[132,838]$ & $565[453,889]$ \\
\hline Day net UF & $254[-80,471]$ & $-96[-166,-91]$ \\
\hline Total peritoneal net UF & $813[123,1067]$ & $472[356,723]$ \\
\hline Diuresis & $600[0,1550]$ & $1150[775,1825]$ \\
\hline Total 24 h water removal & $1592[1314,1806]$ & $1771[1431,2062]$ \\
\hline
\end{tabular}

Table 3. The overall water removal (net UF, median $\left[\mathrm{Q}_{1}, \mathrm{Q}_{3}\right]$ in $\mathrm{mL}$ ) from night APD exchanges and the long daytime exchange, diuresis and total $24 \mathrm{~h}$ water removal, measured in patients undergoing APD with wet day $\left(A P D_{W D}\right)$ or a dry day regime $\left(A P D_{D D}\right)$. No significant differences were found between $A P D_{D D}$ and $A P D_{W D}$ concerning the night and day net UF, total peritoneal net UF, diuresis and total $24 \mathrm{~h}$ water removal $(\mathrm{p}>0.1$; Mann-Whitney U test).
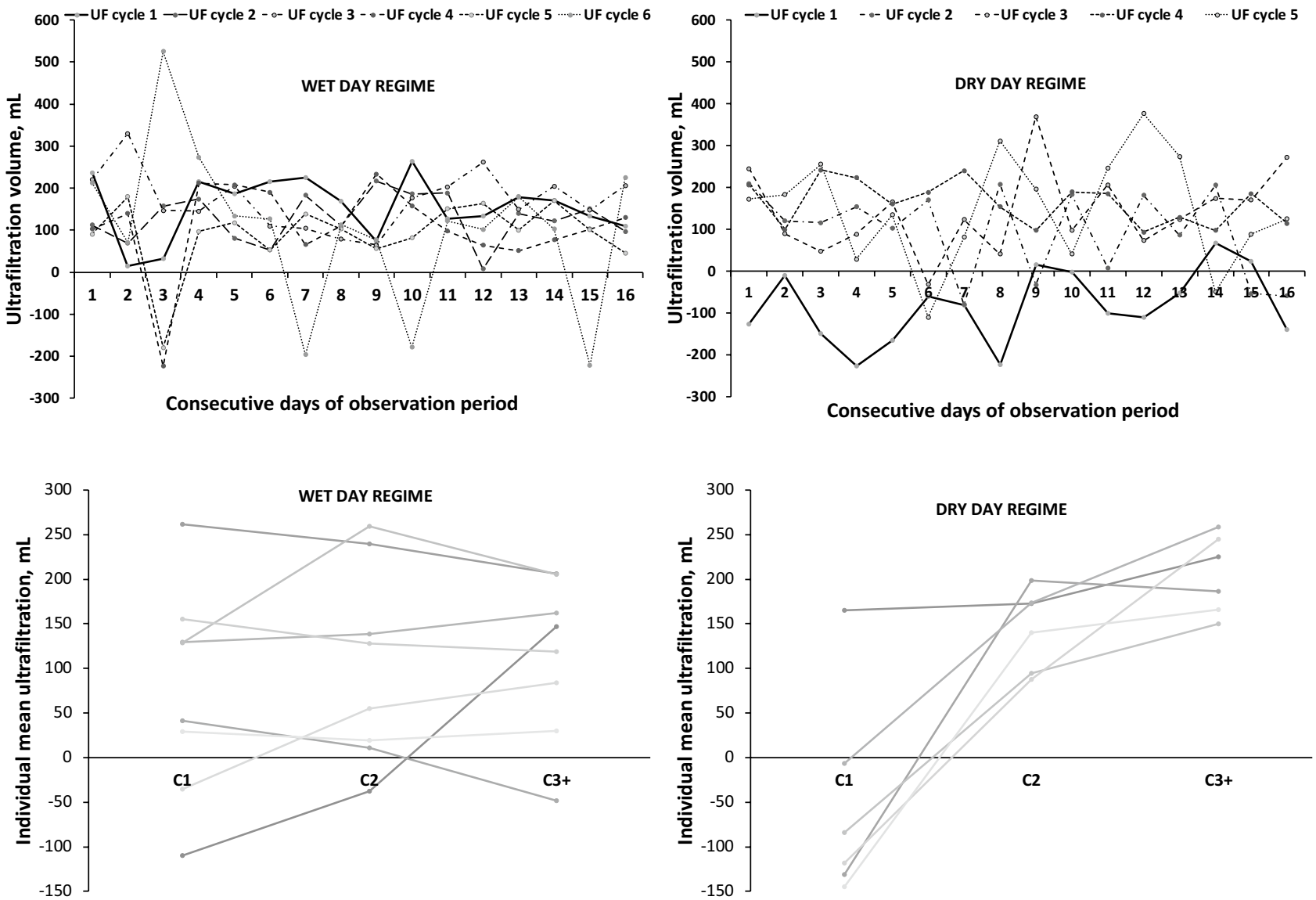

Figure 1. Ultrafiltration patterns during APD according to data delivered by continuous remote monitoring. Upper panel: Net ultrafiltration volume (in $\mathrm{mL}$ ) of each APD exchange during the observation period of 16 days for two patients undergoing $\mathrm{APD}$ with wet day $\left(\mathrm{APD}_{\mathrm{WD}}\right.$ with 6 night exchanges) and dry day ( $\mathrm{APD} \mathrm{DD}_{\mathrm{Dith}} 5$ night exchanges) regimes respectively. Net UF from each cycle/exchange of the APD session is denoted by a different colour. The bold, solid line corresponds to net UF from first cycle obtained during consecutive days. Bottom panel: Individual values of mean net ultrafiltration (in $\mathrm{mL}$ ) in the first $(\mathrm{C} 1)$, and second $(\mathrm{C} 2)$ cycle, and the mean values of the following cycles $(\mathrm{C} 3+)$ during the observation period of 16 days for each of the 14 patients undergoing either $\mathrm{APD}_{\mathrm{WD}}(\mathrm{n}=8)$ or $\mathrm{APD}_{\mathrm{DD}}(\mathrm{n}=6)$.

mean values (over days) of net UF observed in the first $(\mathrm{C} 1)$, second $(\mathrm{C} 2)$, and the following cycles $(\mathrm{C} 3+)$ for each patient from $A P D_{D D}$ and $A P D_{W D}$ group are shown in Fig. 1, bottom panel.

A statistically significant dependence on cycle number was found in the $\mathrm{APD}_{\mathrm{DD}}$ group $(\mathrm{p}<0.001$; ANOVA repeated measurements test) whereas inter-cycle differences of net UF were not statistically significant in $A P D_{W D}$. Further post-hoc analysis showed significantly lower UF in the $\mathrm{APD}_{\mathrm{DD}}$ group for $\mathrm{C} 1 \mathrm{vs}$. $\mathrm{C} 2$ and for $\mathrm{C} 1$ vs. $\mathrm{C} 3+(\mathrm{p} \leq 0.001)$, Table 4 . 


\begin{tabular}{|l|l|l|}
\hline Net UF and drain volume ratio & $\begin{array}{l}\mathbf{A P D}_{\text {WD }} \\
\mathbf{n}=\mathbf{8}\end{array}$ & $\begin{array}{l}\mathbf{A P D}_{\mathbf{D D}} \\
\mathbf{n}=\mathbf{6}\end{array}$ \\
\hline UF in C1, mL & $81[-8,176]$ & $-61[-148,27]$ \\
\hline UF in C2, mL & $81[-4,192]$ & $170[78,228]^{*}$ \\
\hline Mean UF in C3+, mL & $115[4,219]$ & $213[126,275]^{* *}$ \\
\hline VdrR1 & $1.00[0.93,1.04]$ & $0.87[0.81,0.93]^{\#,+}$ \\
\hline VdrR2 & $1.00[0.94,1.04]$ & $0.97[0.92,1.00]^{*, \dagger}$ \\
\hline
\end{tabular}

Table 4. Net peritoneal ultrafiltration (UF, median $\left[\mathrm{Q}_{1}, \mathrm{Q}_{3}\right]$ ) measured for cycle $1(\mathrm{C} 1)$, cycle $2(\mathrm{C} 2)$ and for the mean value from cycle 3 and following cycles $(\mathrm{C} 3+)$, as well as the ratio of drain volumes calculated for first (VdrR1) and second (VdrR2) cycle over a mean value for C3+ for patients undergoing $\mathrm{APD}_{\mathrm{WD}}$ and $\mathrm{APD}_{\mathrm{DD}} \cdot{ }^{*} \mathrm{p} \leq 0.001$; Tukey's post-hoc test comparing $\mathrm{C} 1$ vs. $\mathrm{C} 2,{ }^{* *} \mathrm{p} \leq 0.001$; Tukey's post-hoc test comparing $\mathrm{C} 1$ vs. $\mathrm{C} 3+,{ }^{\#} \mathrm{p}<0.05$; Wilcoxon comparing median values of $\mathrm{VdrR} 1$ with $\mathrm{VdrR} 2,{ }^{\# \#} \mathrm{p}<0.05$; t-test comparing median values of $\mathrm{VdrR}$ for $\mathrm{APD}_{\mathrm{WD}} \mathrm{vs} . \mathrm{APD}_{\mathrm{DD}},{ }^{\dagger} \mathrm{p}<0.05$; Wilcoxon to test if the value is lower than 1 .
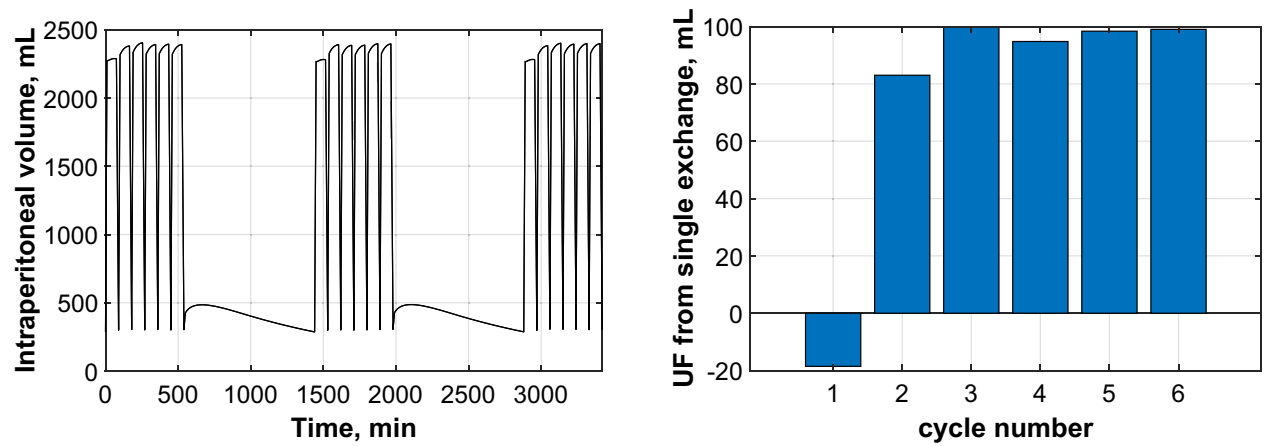

Figure 2. Numerical simulations for a typical $A P D_{D D}$ patient showing negative net UF during the first $A P D$ cycle in contrast to positive net UF during the consecutive five cycles. Intraperitoneal volume profiles as a function of time during three consecutive APD sessions (consisting of six 90-min exchanges with $2 \mathrm{~L}$ of glucose $1.36 \%$ ) interrupted by dry days (with infusion of $100 \mathrm{~mL}$ of glucose $1.36 \%$ ) (left panel) and the corresponding net UF per each of the 6 single exchanges of the last (third) day's APD session (right panel).

Median values of drain volume ratios were below unity in $\mathrm{APD}_{\mathrm{DD}}(\mathrm{VdrR} 1=0.87$ and $\mathrm{VdrR} 2=0.97)$ but not in $\mathrm{APD}_{\mathrm{WD}}$ patients $(\mathrm{VdrR} 1=1.00$ and $\mathrm{VdrR} 2=1.00)$. The individual values of $\mathrm{VdrR} 1$ and $\mathrm{VdrR} 2$ (for all days of the observation period) were significantly lower than one in $\mathrm{APD}_{\mathrm{DD}}$ (both $\mathrm{p}<0.001$ ) but not in $\mathrm{APD}_{\mathrm{WD}}$ patients $\left(p=0.11\right.$ and $p=0.25$, respectively). Moreover, in $A P D_{W D}$, median values of VdrR1 vs. VdrR2 did not differ $(\mathrm{p}=0.73)$ whereas this difference was significant for $\operatorname{APD}_{\mathrm{DD}}(\mathrm{p}=0.03)$. Finally, VdrR differed between $\mathrm{APD}_{\mathrm{WD}}$ and $\mathrm{APD}_{\mathrm{DD}}$ for $\operatorname{VdrR} 1(\mathrm{p}<0.001)$, but not for $\operatorname{VdrR} 2(\mathrm{p}=0.10)$, Table 4.

To explore if lower net UF during initial cycles in the $\mathrm{APD}_{\mathrm{DD}}$ group could be attributed to altered tissue hydration status, data were analysed using the spatially distributed model ${ }^{2,7}$. Numerical simulations for a typical $\mathrm{APD}_{\mathrm{DD}}$ patient showed negative net UF during the first APD cycle in contrast to positive net UF during the consecutive five cycles, Fig. 2.

The distributed model predicted total net UF for the whole APD session of $458 \mathrm{~mL}$, negative ultrafiltration of $-19 \mathrm{~mL}$ during first APD cycle, $83 \mathrm{~mL}$ in $\mathrm{C} 2$, and mean ultrafiltration of $98 \pm 3 \mathrm{~mL}$ during remaining cycles, see Table 5. Net UF for the first APD exchange $(\mathrm{C} 1: \mathrm{UF}=-19 \mathrm{~mL})$ was $114 \mathrm{~mL}$ lower than the mean value of net UF from subsequent five cycles, Fig. 2 and Table 5.

According to the applied model ${ }^{2,7}$, during PD, the inflow of fluid and solutes into the peritoneal tissue, induced by the osmotic force, results in a local increase in interstitial hydrostatic pressure that increases tissue hydration above the physiological level of about $18 \%$ in the layers close to the peritoneal cavity but gradually decreases as a function of increasing distance from the peritoneal cavity, see Fig. 3. In patients on $\mathrm{APD}_{\mathrm{WD}}$, peritoneal tissue hydration in the layers close to the peritoneal cavity remains higher than the physiological state of hydration throughout $24 \mathrm{~h}$ because of the unphysiological presence of dialysis fluid. In contrast, in patients on the APD regime, peritoneal tissue hydration is not constant. After a dry day with almost empty peritoneal cavity, peritoneal tissue hydration at the start of the APD session is only slightly above the physiological hydration of about $18 \%$, see Fig. 3. The inflow of dialysis fluid at the start of the APD session results in an immediate increase of tissue hydration close to the peritoneal cavity with a further increase after the second exchange resulting in a state of tissue overhydration that is typical in PD, Fig. 3. The increase in tissue hydration during the first APD cycle was caused by inflow of $187 \mathrm{~mL}$ of water accumulating in the peritoneal tissue, and by a total accumulation of $269 \mathrm{~mL}$ during the two initial exchanges of APD session, respectively. 


\begin{tabular}{|l|l|}
\hline Fluid removal and fluid accumulation in the tissue & APD $_{\text {DD }}$ with Vinf $=\mathbf{1 0 0} \mathbf{~ m L}$ \\
\hline UF for APD session, $\mathrm{mL}$ & 458 \\
\hline UF in $\mathrm{C} 1, \mathrm{~mL}$ & -19 \\
\hline UF in $\mathrm{C} 2, \mathrm{~mL}$ & 83 \\
\hline Mean $\mathrm{UF}$ in $\mathrm{C} 3+, \mathrm{mL}$ & $98 \pm 3$ \\
\hline Water accumulated in $\mathrm{C} 1, \mathrm{~mL}$ & 187 \\
\hline Water accumulated in $\mathrm{C} 1$ and $\mathrm{C} 2, \mathrm{~mL}$ & 269 \\
\hline
\end{tabular}

Table 5. Volumes of water removal predicted by the distributed model: net UF for the whole APD session, first $(\mathrm{C} 1)$ and second $(\mathrm{C} 2)$ APD cycle and mean \pm SD net UF in consecutive cycles $\left(\mathrm{C}^{+}\right)$, and water accumulation in the peritoneal tissue during the first cycle $(\mathrm{C} 1)$ and during first two cycles $(\mathrm{C} 1$ plus $\mathrm{C} 2)$ for a typical patient undergoing $\mathrm{APD}$ with a dry day regime $\left(\mathrm{APD}_{\mathrm{DD}}\right)$ with infusion of $100 \mathrm{~mL}$ of glucose $1.36 \%$ during the day to prevent pain.

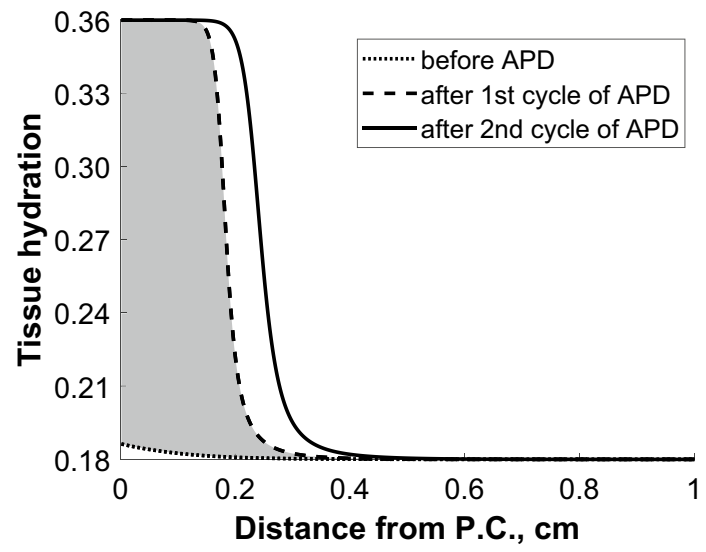

Figure 3. Predictions by the applied distributed model $^{2,7}$ of peritoneal tissue hydration as a function of distance from the peritoneal cavity (P.C.) and changes during APD with dry day followed by night APD exchanges $\left(\mathrm{APD}_{\mathrm{DD}}\right.$ regime). Dotted line-before starting of APD session; dashed line-after the first cycle of APD session; solid line-after the second cycle of APD session. Before starting of APD session, the tissue hydration profile is slightly above the physiological level of tissue hydration of $0.18(18 \%)$ that is typically kept in deeper tissue layers. The shadowed area denotes the change in tissue hydration occurring during the first cycle of APD session due to water absorbed into the peritoneal tissue driven by the high intraperitoneal pressure gradient following the infusion of dialysis fluid. The $\mathrm{APD}_{\mathrm{DD}}$ session was simulated with 6 cycles of 90 min each with an infusion of $2 \mathrm{~L}$ of glucose $1.36 \%$ preceded by a "dry" daytime exchange with an infusion of $100 \mathrm{~mL}$ of glucose $1.36 \%$.

\section{Discussion}

Our analysis of UF data delivered by RPM in APD patients treated at home revealed lower net UF during the first cycle of $A P D$ session in patients using a dry day regime $\left(A P D_{D D}\right)$ as compared to those on a wet day regime $\left(\mathrm{APD}_{\mathrm{WD}}\right)$; and some $\mathrm{APD}_{\mathrm{DD}}$ patients had negative net UF during the first $\mathrm{APD}$ exchange. Peritoneal transport modelling indicated that a likely explanation for this phenomenon is that the daytime exchange influenced the hydration state of the peritoneal membrane and that this affected water removal during the initial exchange(s) of the subsequent APD session. Thus, the observed initial lower efficiency of water removal in patients on the $\mathrm{APD}_{\mathrm{DD}}$ regime appears to be related to a relative increase of peritoneal tissue hydration during the first APD cycles following a dry day.

The acquisition of clinical data relied on the advent of RPM, which was designed to track, on a daily basis, factors such as blood pressure, body weight, dialysis treatment characteristics including ultrafiltration, and patient's adherence to dialysis prescriptions in patients undergoing APD at home ${ }^{8}$, and which offers unique opportunities for studies of net UF of APD exchanges cycle-by-cycle. To the best of our knowledge, this is the first detailed study of UF patterns during APD using this technology.

Lower UF volumes during the initial as compared to subsequent cycles was demonstrated in $\mathrm{APD}_{\mathrm{DD}}$ but not in $\mathrm{APD}_{\mathrm{WD}}$ when analysing drain volume ratios (of initial cycle volume to subsequent cycle volumes): in $\mathrm{APD} \mathrm{DD}_{\mathrm{DD}}$, but not in $\mathrm{APD}_{\mathrm{WD}}$, VdrR1 was lower than VdrR2 and both ratios were significantly lower than 1 (Table 4). Moreover, VdrR was lower in $\mathrm{APD}_{\mathrm{DD}}$ than in $\mathrm{APD}_{\mathrm{WD}}$ indicating that the daytime exchange influenced water removal during the subsequent $\mathrm{APD}_{\mathrm{DD}}$ session. We have not identified any published studies describing this phenomenon.

To further explore why $\mathrm{APD}_{\mathrm{DD}}$ patients had lower net UF during the first cycles of $\mathrm{APD}$, we performed numerical simulations based on the distributed model ${ }^{2,7}$ for a typical $\mathrm{APD}_{\mathrm{DD}}$ patient with standard prescription (vide supra, and Table 2). These simulations provided results which fit well with clinical data. Thus, while 
the simulated net UF of the daytime exchange was $-110 \mathrm{~mL}$ and $458 \mathrm{~mL}$ for the whole night APD session, the corresponding values in the subgroup of $\mathrm{APD}_{\mathrm{DD}}$ patients (with glucose $1.36 \%$ prescribed) was $-188 \mathrm{~mL}$ and $440 \mathrm{~mL}$ respectively.

Using the applied model, we explored changes in the hydration status of the peritoneal tissue, which is typically not considered in physiological interpretations, and in most mathematical models of the peritoneal transport it is assumed constant ${ }^{3,7,11,12}$. However, water reabsorption from the peritoneal cavity (driven by the high intraperitoneal pressure gradient) to the adjacent tissue layers may correspond to more than $70 \%$ of total peritoneal fluid absorption ${ }^{13}$. The water inflow into the peritoneal tissue induces an increase of interstitial pressure and tissue hydration over their physiological levels. Such an increase, observed also in inflammation, facilitates water and solute transport by changing transport properties of the peritoneal membrane. During the treatment, the interstitial pressure close to the peritoneal cavity increases to equilibrate with the intraperitoneal pressure. Such an increase of interstitial pressure and the corresponding increase in tissue hydration in the layer close to the peritoneal cavity is predicted by the applied distributed model but was also observed experimentally in an animal model of PD and in basic physiology studies $2,6,7,11,14,15$.

Numerical simulations were performed for the standard distributed model that takes into account the spatial character of the peritoneal barrier and was validated previously based on clinical and experimental data. In the model, the functional relation between dynamic changes of the tissue hydration and interstitial pressure and their impact on the local transport properties were considered (based on the experimental data). Analysis based on this model showed increase of tissue hydraulic conductivity and solute diffusivity close to the peritoneal cavity (within $0.2 \mathrm{~cm}$ distance from the peritoneal surface) caused by the local increase of tissue hydration and interstitial pressure or local increase of tissue lymphatic absorption or permeability caused by the local interstitial pressure increase (as a part of edema preventing mechanism). All these mechanisms have been investigated experimentally previously and corresponding functional relations were validated in the earlier versions of the model and were used in the present version of the model, $\operatorname{see}^{2,6,7,11,16-19}$. It should be noted that the increase of tissue hydration, observed during the peritoneal dwell, is restricted to the thin layer of $0.2 \mathrm{~cm}$ width measured from the peritoneal surface, see Fig. 3, and does not reflect changes in the deeper tissue layers or in the fluid status of the whole body where hydration may remain unchanged. Moreover, the spatial character of the barrier results in a non-constant glucose profile across the peritoneal barrier (exponentially decaying, see for example Flessner et al. $^{20}$ ) that has local vasodilatory effect on tissue blood capillaries situated within short distance from the peritoneal cavity. The detailed mechanism of the vasodilation in case of PD has been investigated experimentally by Zakaria et al..$^{21-25}$ and the functional relation was implemented in the currently applied model that considers changes in the effective surface area of the blood capillary wall without detailed modelling of mechanisms. One may also speculate that high glucose concentration, as present in the dialysis fluid and locally in the tissue close to the peritoneal cavity, may lead to the local increase of AQP-1 expression as has been shown in in vitro studies for endothelial and mesothelial cells by Lai et al. ${ }^{26}$ and modelled using the three-pore model by StachowskaPietka et al. ${ }^{27}$. This would result in similar changes as those induced by local vasodilation. Nevertheless, numerical simulation of the DD cycles showed that although the same functional relations of physiological properties were assumed, the differences in tissue hydration between cycles led to the different local tissue properties and, in consequence, different treatment effectiveness. During a dry day regime $\left(\mathrm{APD}_{\mathrm{DD}}\right)$, when the peritoneal cavity is empty or almost empty, intraperitoneal pressure remains lower than the interstitial pressure in the adjacent tissue layers, leading to slow leakage of water accumulated in the tissue into the peritoneal cavity. Consequently, peritoneal tissue hydration decreases to the physiological (lower) state of tissue hydration. At the beginning of $\mathrm{APD}_{\mathrm{DD}}$ session, the infusion of hypertonic dialysis fluid not only induces ultrafiltration into the peritoneal cavity due to the osmotic force. Besides, a part of the water remains in the tissue and increases its hydration, adapting to the PD condition by equilibrating with the fluid in the peritoneal cavity. In contrast, during a wet day regime $\left(\mathrm{APD}_{\mathrm{WD}}\right)$, tissue hydration during the day remains unphysiologically high (as is typical for continuous forms of $\mathrm{PD})$ due to the presence of dialysate throughout the day, resulting in elevated intraperitoneal pressure during daytime. Therefore, any decrease of tissue hydration after a daytime exchange is negligible and there is only a minor (within measurement error) impact on water removal during the subsequent initial APD cycles.

Some strengths and limitations of the study should be noted. Strengths include the availability of detailed data of net UF cycle-by-cycle provided by RPM in two similar groups of patients using the two APD regimes and the long observation period (16 days) in each patient. However, one cannot exclude that at least part of the UF variability between cycles, as observed in our study, might be related also to other factors that are not considered in the applied model, such as changes in the residual peritoneal volume (due to differences in drainage), physical activity of the patients that influences intraperitoneal pressure (such as coughing, patient's posture during drainage), diuresis, and overall volume status. Therefore, in contrast to solute removal which can be predicted very precisely by available peritoneal transport models, peritoneal ultrafiltration is difficult to predict.

In general, the residual volume may differ not only between patients but also between APD cycles, having an impact on the evaluation on the water removal from each exchange. The impact of possible differences in residual volumes before each APD cycle might be especially important in case of APD with low glucose solution, due to the relatively small ultrafiltered volume per cycle. The precise evaluation of the residual volume would require additional procedures performed before each cycle such as rinse procedure (to evaluate residual volume from dilution technique) or usage of a volume marker, that were outside the scope of the study. Therefore, for the purpose of this study, it was assumed that the residual volume is not changing between cycles of APD sessions for a particular patient. Moreover, we assumed that the impact of the difference in intraperitoneal volume remaining after daytime exchange on the initial drainage before APD session (DD vs WD regime) is compensated by the default settings of the cycler (setting the same initial draining force, and automatically stopping drainage if the fluid flow rate is too low) as suggested by our data. We found that the average amount of drained volume in the group of $\mathrm{APD}_{\mathrm{WD}}, 1812$ [2111-1270] ml (median value with range [Q3-Q1]), was significantly higher than the 
corresponding value for $\mathrm{APD}_{\mathrm{DD}}$ group, 27 [101-4] mL. Nevertheless, this would not influence our findings since they were mostly based on the analysis comparing cycles within the same patient and for the same APD regime. The only comparison between the two regimes was done based on the drained volumes ratio, VdrR (Table 4), which showed significant difference between the two APD regimes even when excluding the first cycle (VdrR2) and after correcting for fluid tonicity.

The low number of patients in each of the studied groups is another limitation; further investigations of larger cohorts of patients are warranted to confirm our findings. One problem with the selection of patients for this kind of clinical study is that many patients using cyclers change glucose concentration of dialysis fluid cycle-to-cycle during the night exchanges due to changed prescription, and therefore only a rather low number of patients use the same glucose concentration in all cycles. In our study only patients using dialysis fluid with constant glucose concentration were investigated. Moreover, although both studied groups had statistically similar characteristics, there was a tendency for faster transport status in $\mathrm{APD}_{\mathrm{DD}}$ than in $\mathrm{APD}_{\mathrm{WD}}$ group, that might have a slight effect on the comparison of both groups but not the results in each group separately. Furthermore, a difference between the groups is that all but one of the $\mathrm{APD}_{\mathrm{WD}}$ patients used icodextrin-based dialysis fluid during the long day dwell that significantly increases net $\mathrm{UF}^{28-32}$ and may have a different impact on peritoneal tissue hydration. Nevertheless, we believe that presented results supported by the mathematical modelling for a typical patient indicate a possible reason for at least part of the observed variability in the water removal between consecutive APD cycles. It should be noted however that there was no difference between the two APD regimes concerning the total obtained volume of net UF from the night and day exchanges and $24 \mathrm{~h}$ UF, Table 3 . Moreover, although we observed lower efficiency of water removal during initial $\mathrm{APD}_{\mathrm{DD}}$ cycles in our patients, this effect was relatively minor from a clinical point of view. However, the role of this phenomenon in other situations-such as in case of adapted APD schedules with variable dwell time being combined with variable dwell volumes ${ }^{33}$, use of different glucose concentrations, or in case of patients with different transport characteristics or different diuresis-is not clear and needs further investigations.

In summary, our investigation of ultrafiltration cycle-by-cycle during APD assessed by remote monitoring of patients treated at home revealed that compared with a "wet day" APD regime $\left(A P D_{W D}\right)$, patients on a "dry day" $\mathrm{APD}$ regime $\left(\mathrm{APD}_{\mathrm{DD}}\right)$ had lower water removal during the first as compared to subsequent $\mathrm{APD}$ cycles, and in some cases even negative UF. According to peritoneal transport modelling, the observed difference in initial UF between the two regimes may reflect local adaptation of the peritoneal tissue to the presence $\left(\mathrm{APD}_{\mathrm{WD}}\right)$ vs. absence $\left(\mathrm{APD}_{\mathrm{DD}}\right)$ of dialysis fluid in the peritoneal cavity during the long daytime dwell. During the dry day $\left(\mathrm{APD}_{\mathrm{DD}}\right)$, peritoneal tissue hydration decreases towards a physiological level of about $18 \%$ and then increases during the first APD cycle to about $36 \%$ (in tissue layer close to the peritoneal cavity), a level typical for conditions with continuous presence of dialysis fluid such as in $\mathrm{APD}_{\mathrm{WD}}$. We conclude that the increase of peritoneal tissue hydration during the first $\mathrm{APD}$ cycle in $\mathrm{APD}_{\mathrm{DD}}$ patients appears to be a consequence of inflow of water into the peritoneal tissue-thereby reducing the inflow into the peritoneal cavity-resulting in a corresponding decrease of net UF.

\section{Data availability}

A detailed description of the mathematical model used in this study and values of all model parameters may be found in the Supplementary material and in our previous work referenced in the manuscript. Anonymized clinical data are available on request.

Received: 16 April 2021; Accepted: 19 July 2021

Published online: 02 August 2021

\section{References}

1. Brown, E. A. et al. Survival of functionally anuric patients on automated peritoneal dialysis: The European APD Outcome Study. J. Am. Soc. Nephrol. 14, 2948-2957. https://doi.org/10.1097/01.asn.0000092146.67909.e2 (2003).

2. Stachowska-Pietka, J., Poleszczuk, J., Flessner, M. F., Lindholm, B. \& Waniewski, J. Alterations of peritoneal transport characteristics in dialysis patients with ultrafiltration failure: Tissue and capillary components. Nephrol. Dial. Transplant 34, 864-870. https://doi. org/10.1093/ndt/gfy313 (2019).

3. Oberg, C. M. \& Rippe, B. Optimizing automated peritoneal dialysis using an extended 3-pore model. Kidney Int. Rep. 2, 943-951. https://doi.org/10.1016/j.ekir.2017.04.010 (2017).

4. Heimburger, O., Waniewski, J., Werynski, A. \& Lindholm, B. A quantitative description of solute and fluid transport during peritoneal dialysis. Kidney Int. 41, 1320-1332. https://doi.org/10.1038/ki.1992.196 (1992).

5. Coester, A. M., Smit, W., Struijk, D. G., Parikova, A. \& Krediet, R. T. Longitudinal analysis of peritoneal fluid transport and its determinants in a cohort of incident peritoneal dialysis patients. Perit. Dial. Int. 34, 195-203. https://doi.org/10.3747/pdi.2012. 00189 (2014).

6. Flessner, M. F. Osmotic barrier of the parietal peritoneum. Am. J. Physiol. 267, F861-870. https://doi.org/10.1152/ajprenal.1994. 267.5.F861 (1994).

7. Stachowska-Pietka, J., Waniewski, J., Flessner, M. F. \& Lindholm, B. Computer simulations of osmotic ultrafiltration and smallsolute transport in peritoneal dialysis: A spatially distributed approach. Am. J. Physiol. Renal Physiol. 302, F1331-1341. https:// doi.org/10.1152/ajprenal.00301.2011 (2012).

8. Sanabria, M. et al. Remote patient monitoring program in automated peritoneal dialysis: Impact on hospitalizations. Perit. Dial. Int. 39, 472-478. https://doi.org/10.3747/pdi.2018.00287 (2019).

9. Drepper, V. J., Martin, P. Y., Chopard, C. S. \& Sloand, J. A. Remote patient management in automated peritoneal dialysis: A promising new tool. Perit. Dial. Int. 38, 76-78. https://doi.org/10.3747/pdi.2017.00054 (2018).

10. Ronco, C. et al. Remote patient management of peritoneal dialysis during COVID-19 pandemic. Perit. Dial. Int. 40, 363-367. https://doi.org/10.1177/0896860820927697 (2020).

11. Zakaria, E. R., Lofthouse, J. \& Flessner, M. F. Effect of intraperitoneal pressures on tissue water of the abdominal muscle. Am. J. Physiol. Renal Physiol. 278, F875-885. https://doi.org/10.1152/ajprenal.2000.278.6.F875 (2000). 
12. Fischbach, M., Issad, B., Dubois, V. \& Taamma, R. The beneficial influence on the effectiveness of automated peritoneal dialysis of varying the dwell time (short/long) and fill volume (small/large): A randomized controlled trial. Perit. Dial. Int. 31, 450-458. https://doi.org/10.3747/pdi.2010.00146 (2011).

13. Fischbach, M., Schmitt, C. P., Shroff, R., Zaloszyc, A. \& Warady, B. A. Increasing sodium removal on peritoneal dialysis: Applying dialysis mechanics to the peritoneal dialysis prescription. Kidney Int. 89, 761-766. https://doi.org/10.1016/j.kint.2015.12.032 (2016).

14. Wiig, H. \& Reed, R. K. Compliance of the interstitial space in rats. II. Studies on skin. Acta Physiol. Scand. 113, 307-315 (1981).

15. Wiig, H., Reed, R. K. \& Aukland, K. Measurement of interstitial fluid pressure: Comparison of methods. Ann. Biomed. Eng. 14, 139-151 (1986).

16. el Zakaria, R., Lofthouse, J. \& Flessner, M. F. In vivo hydraulic conductivity of muscle: Effects of hydrostatic pressure. Am. J. Physiol. 273, H2774-2782. https://doi.org/10.1152/ajpheart.1997.273.6.H2774 (1997).

17. Aukland, K. \& Reed, R. K. Interstitial-lymphatic mechanisms in the control of extracellular fluid volume. Physiol. Rev. 73, 1-78 (1993).

18. Stachowska-Pietka, J., Waniewski, J., Flessner, M. F. \& Lindholm, B. Distributed model of peritoneal fluid absorption. Am. J. Physiol. Heart Circ. Physiol. 291, H1862-1874. https://doi.org/10.1152/ajpheart.01320.2005 (2006).

19. Waniewski, J., Stachowska-Pietka, J. \& Flessner, M. F. Distributed modeling of osmotically driven fluid transport in peritoneal dialysis: Theoretical and computational investigations. Am. J. Physiol. Heart Circ. Physiol. 296, H1960-1968. https://doi.org/10. 1152/ajpheart.00121.2009 (2009).

20. Flessner, M. F., Dedrick, R. L. \& Reynolds, J. C. Bidirectional peritoneal transport of immunoglobulin in rats: Tissue concentration profiles. Am. J. Physiol. 263, F15-23 (1992).

21. Zakaria, E. R., Althani, A., Fawzi, A. A. \& Fituri, O. M. Molecular mechanisms of peritoneal dialysis-induced microvascular vasodilation. Adv. Perit. Dial. 30, 98-109 (2014).

22. Zakaria, E. R., Althani, A., Fawzi, A. A. \& Fituri, O. M. Hyperosmolality-mediated peritoneal microvascular vasodilation is linked to aquaporin function. Adv. Perit. Dial. 30, 63-74 (2014).

23. Zakaria, E. R., Hunt, C. M., Li, N., Harris, P. D. \& Garrison, R. N. Disparity in osmolarity-induced vascular reactivity. J. Am. Soc. Nephrol. 16, 2931-2940. https://doi.org/10.1681/asn.2004090764 (2005)

24. Zakaria, E. R., Patel, A. A., Li, N., Matheson, P. J. \& Garrison, R. N. Vasoactive components of dialysis solution. Perit. Dial. Int. 28, 283-295 (2008).

25. Zakaria, E. R., Spain, D. A., Harris, P. D. \& Garrison, R. N. Generalized dilation of the visceral microvasculature by peritoneal dialysis solutions. Perit. Dial. Int. 22, 593-601. https://doi.org/10.1177/089686080202200510 (2002).

26. Lai, K. N. et al. Expression of aquaporin-1 in human peritoneal mesothelial cells and its upregulation by glucose in vitro. J. Am. Soc. Nephrol. 12, 1036-1045 (2001).

27. Stachowska-Pietka, J., Waniewski, J., Vonesh, E. \& Lindholm, B. Changes in free water fraction and aquaporin function with dwell time during continuous ambulatory peritoneal dialysis. Artif. Organs 34, 1138-1143. https://doi.org/10.1111/j.1525-1594.2010. 01036.x (2010).

28. Olszowska, A. et al. Long peritoneal dialysis dwells with icodextrin: Kinetics of transperitoneal fluid and polyglucose transport. Front. Physiol. 10, 1326. https://doi.org/10.3389/fphys.2019.01326 (2019).

29. Olszowska, A. et al. The kinetics of water transperitoneal transport during long-term peritoneal dialysis performed using icodextrin dialysis fluid. Pol. Arch. Med. Wewn 119, 305-310 (2009).

30. Leypoldt, J. K., Hoff, C. M., Akonur, A. \& Holmes, C. J. Low-polydispersity glucose polymers as osmotic agents for peritoneal dialysis. Perit. Dial. Int. 35, 428-435. https://doi.org/10.3747/pdi.2013.00232 (2015).

31. Goossen, K. et al. Icodextrin versus glucose solutions for the once-daily long dwell in peritoneal dialysis: An enriched systematic review and meta-analysis of randomized controlled trials. Am. J. Kidney Dis. 75, 830-846. https://doi.org/10.1053/j.ajkd.2019.10. $004(2020)$.

32. Mistry, C. D., Gokal, R. \& Peers, E. A randomized multicenter clinical trial comparing isosmolar icodextrin with hyperosmolar glucose solutions in CAPD. MIDAS Study Group. Multicenter investigation of icodextrin in ambulatory peritoneal dialysis. Kidney Int. 46, 496-503. https://doi.org/10.1038/ki.1994.300 (1994).

33. Oberg, C. M. \& Rippe, B. Is adapted APD theoretically more efficient than conventional APD?. Perit. Dial. Int. 37, 212-217. https:// doi.org/10.3747/pdi.2015.00144 (2017).

\section{Acknowledgements}

We thank the patients who participated in the study and all nurses who helped with collecting clinical data. Baxter Novum is the result of a grant from Baxter Healthcare to Karolinska Institutet. The funders of this study had no role in the study design, data collection, data analysis, or interpretation, writing of the report, or the decision to submit the report for publication.

\section{Author contributions}

J.S.-P., B.N., R.G., J.W., and B.L. conceived and designed the study, J.S.-P. developed the mathematical model and performed simulations; J.S.-P. and E.S. collected all clinical data; J.S.-P. and J.W. analysed and interpreted the results; J.S.-P. drafted the manuscript and prepared figures and tables; All authors reviewed, revised, and approved the final version of the manuscript.

\section{Competing interests}

B. L. and R. G. are employees of Baxter Healthcare Corporation. B. N. and E. S. acknowledge consultancy for Baxter Healthcare Corporation outside the submitted work. J. S-P and J. W. and E. S. declare no conflict of interest.

\section{Additional information}

Supplementary Information The online version contains supplementary material available at https://doi.org/ 10.1038/s41598-021-95001-x.

Correspondence and requests for materials should be addressed to J.S.-P.

Reprints and permissions information is available at www.nature.com/reprints.

Publisher's note Springer Nature remains neutral with regard to jurisdictional claims in published maps and institutional affiliations. 
(c) (i) Open Access This article is licensed under a Creative Commons Attribution 4.0 International cc) License, which permits use, sharing, adaptation, distribution and reproduction in any medium or format, as long as you give appropriate credit to the original author(s) and the source, provide a link to the Creative Commons licence, and indicate if changes were made. The images or other third party material in this article are included in the article's Creative Commons licence, unless indicated otherwise in a credit line to the material. If material is not included in the article's Creative Commons licence and your intended use is not permitted by statutory regulation or exceeds the permitted use, you will need to obtain permission directly from the copyright holder. To view a copy of this licence, visit http://creativecommons.org/licenses/by/4.0/.

(C) The Author(s) 2021 